\title{
Szülők véleménye az óvodáskorú gyermekek IKT-eszköz használatának negatív és pozitív hatásairól
}

\section{B. Németh Mária ${ }^{1}$, Hódi Ágnes ${ }^{2}$, Juhász Fruzsina ${ }^{3}$, Sárik Anett ${ }^{4}$ és Tóth Edit ${ }^{5}$}

${ }^{1}$ SZTE BTK Neveléstudományi Intézet Pedagógiai Értékelés és Tervezés Tanszék ${ }^{2}$ SZTE JGYPK Alkalmazott Pedagógiai Intézet - Óvodapedagógus-képzö Tanszék

${ }^{3}$ Szegedi Radnóti Miklós Kísérleti Gimnázium, Szeged

${ }^{4}$ Ceglédberceli Általános Müvelödési Központ Napsugár Tagóvodája és Alma Bölcsődéje ${ }^{5}$ MTA-SZTE Képességfejlödés Kutatócsoport

\begin{abstract}
Absztrakt
Hazánkban is érvényes tendencia az, hogy egyre több 6 évnél fiatalabb gyermek használ IKT-eszközt (Livingstone, Haddo \& Gorzig, 2012) és van kitéve a technológia hatásainak otthonában. A család IKT-használathoz való hozzáállása, mintaadása jelentősen befolyásolja az óvodáskorúak digitális eszközhasználatának mennyiségét és minőségét (Kalaš, 2010). Számos óvodáskorú gyermek szülei engedélyezik az IKT-eszközök és digitális tartalmak használatát akár tudásszerzés, akár szabadidős céllal. Hazai vizsgálatok is rámutattak, hogy jelentős arányuk tudatos eszközhasználó és odafigyel arra, gyermeke hogyan, mire használja a technológiát és megismeri a programot mielőtt megengedi annak használatát (Hódi et al., 2019). Hiányzik azonban a kirakó azon fontos darabja, amely a szülők közvetítő viselkedését irányító motívumokra világít rá, arra, hogy a szülők hogyan vélekednek az IKT-eszközök pozitív és negatív hatásairól, ezen vélekedések hogyan orientálják őket gyermekeik digitális szocializációjában. Jelen tanulmányban közölt adatok erre a hazai tekintetben hiányos, ezidáig kismintás zárt kérdőíves méréssel vizsgált tudásszeletre vonatkoznak

Egy nagyváros önkormányzati fenntartású óvodáiban végezett kutatásunkban megkértük a szülőket ( $N=3$ 969), fejtsék ki véleményület az IKT-eszköz használat pozitív és negatív hatásairól óvodás korban. A technológia pozitív hatásairól 1507 (78,5\%), negatív hatásairól 1545 (82,14\%) szülő fejtette ki véleményét, melyeket tartalomelemzéssel a megalapozott elmélet (grounded theory) módszerével dolgoztuk fel.

Vizsgálatunkban az IKT jótékony hatását a szülők jellemzően a tudás megszerzésében (86,79\%), a fejlődés és a tanulás lehetőségében (32,91\%), illetve az információhoz való hozzáférésben (15,79\%) látják. A megkérdezettek úgy gondolják (22,36\%), a korai IKT-tapasztalatok előkészítik a későbbi tanulmányokat és a gyermekeknek könnyebb lesz az iskolában. Válaszadóink között többen (5,37\%) pozitívan értékelik, hogy a digitális média szórakoztatja, leköti a gyermekeket, mikor ők elfoglaltak.
\end{abstract}


Az IKT-használat rizikóját a szülők többsége (63,24\%) a nemkívánt viselkedésben, azon belül a függővé válásban és az agresszív, erőszakos magatartásban látja. A válaszadók több, mit egyharmada szerint nem jó, hogy a gyermekek a digitális eszközök miatt elutasítják a valós, fizikai térben végzett tevékenységeket, kevesebbet mozognak és játszanak a társaikkal, beszűkülnek a személyes jelenléttel járó kapcsolataik. Közel ugyanennyien (31,65\%) gondolják, hogy az IKT-tevékenység testi, kognitív, pszichés, és szocializációs zavarokat idéz elő.

A válaszok arra utalnak, hogy a szülők esetünkben is alapvetően pozitívnak ítélik az IKT technológiák hatásait, de kevésbé tudják azonosítani azokat. A megnevezett kockázatok ugyanakkor más kutatásokhoz hasonlóan relatíve jól behatárolható kategóriákba sorolhatók (lásd Chaudron, 2015; Kalaš, 2010).

Kulcsszavak: IKT-használat, szülői ítéletek, pozitív hatás, IKT-használat veszélyei

A ma óvodásai már digitális otthonokba születtek, digitális bennszülöttek (Kucirkova, 2011; Plowman, 2014; Plowman, Stevenson, Stephen és McPake, 2012) és a technológiával nőnek fel (Brito \& Ramos, 2016, p. 43). Az infokommunikációs technológia (IKT) beépült a családi otthonok infrastruktúrájába (Anderson et al., 2003; Johnson \& Puplampu, 2008), használata a családi élet részévé vált. Ma az étkezőasztálnál online és offline családtagok ülnek, olyanok, akiknek van és akiknek nincs okostelefonjuk. Sok szülő okostelefonnal a kezében tolja a babakocsit, hintáztatja gyermekét a játszótéren, dokumentálja gyermeke mindennapjait és posztolja azt. A mai kisgyermekes családokban a technológia digitális cumiként ${ }^{1}$, (Donoso \& Ribbens, 2014; Wartella et al., 2013), bébiszitterként (Plowman \& McPake, 2013) funkcionál, vagy éppen a motiválás (jutalmazás, illetve büntetés) eszköze (Chiong \& Shuler, 2010; Horst, 2010; Se. \& Lee, 2017; Wartella, Rideout, Lauricella \& Connell, 2013).

Emellett számos szülő aggódik a mindennapokat behálózó IKT nemkívánt hatásai miatt is. Harcolnak a felmerülő problémákkal, például nehezen tudják kontrollálni gyermekük tartalomfogyasztását, képernyőidejét (Ofcom, 2018), a használat korlátozása ellenállást (dacot, dühöt) vált ki. Számos felnőttnek bűntudata van, hogy „kütyükkel” helyettesíti személyes jelenlétét gyermeke életében. Szoronganak, mert úgy érzik, azok használata inkább szolgálja a saját, mint gyermekeik érdekeiket, szükségleteit (Seo \& Lee, 2017). Sokan aggódnak, hogy nemkívánt hatásoknak teszik ki gyermeküket annak ellenére, hogy igyekeznek legjobb tudásuk és meggyőződésük szerint irányítani, mediálni gyermekük IKT-használatát (Livingstone \& Das, 2010; Seo \& Lee, 2017).

A szülők jellemzően nem tervezett stratégiákkal irányítják gyermekeik fejlődését, általában ösztönösen, érzelmeiktől vezérelve döntenek az adott helyzetekben (Plowman et al. 2011). Kutatások szerint a szülők a gyermekek

\footnotetext{
${ }^{1}$ Miner \& Company Research. 2015. www.minerandcostudio.com
} 
médiafogyasztását közvetítő viselkedését tapasztalataik, az IKT használatában való jártasságuk, az arról alkotott véleményük határozza meg (Chaudron, 2015; Cingel \& Krcmar, 2013). Egyre több empirikus vizsgálat mutat rá a tudatosság fontosságára a szülői szerepben (Corthorn \& Milicic, 2016). A gyermekek eszközhasználatának megértésében tehát kritikus jelentőségű a szülők technológiához való viszonyulásának, érzelmeinek ismerete (Kalaš, 2010), különösen kisgyermekkorban, amikor ők az elsődleges irányítók, lényegében tőlük függ, hogy gyermekük, milyen eszközt, milyen tartalommal és mennyi ideig használ (Kalaš, 2010; Lee et al., 2014). Folyamatosan gyűlnek a kisgyermekek (0-8 éves) digitális gyakorlatának megértését segítő adatok, a legtöbb kutatás a nyolc évnél fiatalabb gyermekekre irányul és egy kiválasztott típusú IKT-eszközre vagy tevékenységre fókuszál (Lauricella et al., 2015; Livingstone et al., 2018; McPake et al., 2014; O’Neill, 2015), a szülök szerepére vonatkozóan főleg a technológia közvetítésnek módját, a mediáció stratégiáit tanulmányozza (Durak \& Kaygin, 2020; Clark, 2011; Dias et al., 2016; Nikken \& Schols, 2015; Sonck et al., 2013; Shin \& Li, 2017; Zaman et al., 2016) és nem jellemző a gyermekek IKT-használatát irányító attitűdök vizsgálta.

\section{Az IKT közvetítésében meghatározó szülői perspektívákról eddig összegyüjtött adatok.}

Az IKT közvetítésében meghatározó szülői perspektívákról eddig összegyűjtött adatok néhány nagymintás, az eszközhasználatra irányuló zárt kérdőíves vizsgálatból (például Bakó \& Ráb, 2009; Formby, 2014; OfCom jelentések), és kismintás, 10-70 család megfigyeléséből és félig strukturált interjúkból, jellemzően nem a szülői attitűdök feltárását célzó kutatásokból származnak (például Se. \& Lee, 2017; Zaman et al., 2016). Nagymintás (500 fő feletti) kvalitatív nyílt kérdőíves vizsgálatra nem találtunk adatokat. Jelen tanulmány az „IKT eszközök használata óvodás korban” címü kutatás eredményeit, egy nagyvárosban élő óvodáskorú gyermekek szüleinek IKT-hoz való viszonyát, a kisgyermekek IKT-tevékenységének előnyeiről és hátrányairól való vélekedését mutatja be. A tanulmányban az „infokommunikációs technológia” (IKT) kifejezést inkluzív értelmezésben használjuk, amely magában foglalja az eszközök és tartalom széles skáláját. Szinonimákként használjuk a „technológia” és az IKT, továbbá az „IKT-használat”, az „IKT-tevékenység”, az „eszközhasználat” kifejezéseket (Plowmann, 2016).

\section{A kutatás elméleti háttere}

A családi otthonok digitalizálódása következtében nagy számban és egyre fiatalabb gyermekek kerülnek interakcióba a különféle infokommunikációs technológiákkal és használják maguk is azokat (Holloway et al., 2013; Kucirkova, 2011; Plowman et al., 2012). 2017-ben az Egyesült Királyság otthona- 
iban táblagéphez az óvodáskorú gyermekek 65\%-a fért hozzá. Az Egyesült Államokban mobil eszközök (okostelefon, táblagép) a háztartások 98\%-ban voltak elérhetők és azokat a gyermekek 84\%-a használta (OfCom, 2017; Rideout, 2017). 2016-ban Ausztráliában a gyermekes háztartások 97\%-ban volt laptop vagy asztali számítógép, $86 \%$-a rendelkezett mobiltelefonnal és 62\%-ban volt táblagép (Ausztrál Statkidisztikai Hivatal, 2016). Hódi, Tóth, B. Németh és Fáyné (2019) kutatásában 2018-ban a vizsgált nagyvárosban az óvodások egyharmadának (31,30\%-ának) volt valamilyen IKT-eszköze, és a kiscsoportosok háromnegyede, a nagycsoportosok 86\%-a végzett valamilyen médiatevékenységet. A különböző online platformokon számos táblagéppel vagy mobil telefonnal ügyködő/foglalatoskodó „mobil csecsemő” látható. Egy 2005-2008 között végzett longitudinális vizsgálat szerint a new york-i Bellevue Hospital Center-ben született gyermek 96,1\%-a volt kitéve médiahatásoknak már 6 hónapos korban (Tomopoulos et al., 2010) - Egyre több a kifejezetten csecsemőknek és kisgyermekeknek készült ingyenes vagy nagyon olcsó alkalmazás (Kucirkova, 2011), szoftver, babavideó, számítógépes játék webhely (Rideout \& Hamel, 2006).

Kutatások szerint kora- és kisgyermekkorban a mobil, érintőképernyős eszközök (a táblagépek, okostelefonok) a legnépszerübbek, legvonzóbbak az ideálisabb képernyőméretü táblagépek (Bavelier \& Takeuchi, 2016; Chaudron, 2015; Chaudron et al., 2015a; Dardanou et al., 2020; Livingstone et al., 2015; Plowman, 2015, Hódi et al., 2019). A tableteket mind a szülők, mind a gyermekek a játék, a szórakozás eszközének tekintik (Briro \& Dias, 2016; Donoso \& Ribben, 2014), ugyanakkor a fejlesztés eszközeként is számon tartják azokat (Hódi et al., 2019). Mint egy anya megjegyezte, a tablet az új „örökké a legjobb barát” („best friend forever”- BFF; Britó \& Dias, 2016. p. 38). Koraés kisgyermekkorban leginkább videojátékok, YouTube videók használta jellemző (Brito \& Ramos 2016; Marsh et al., 2017). A szülők szerint a 4-13 éves gyermekek közel fele (47\%) minden nap, 40\% pedig hetente többször játszik digitális játékokat (Bavelier \& Takeuchi, 2016). A gyermekek IKT-tevékenysége ugyanakkor sokféle, például zenét hallgatnak, de szelfiznek, képeket és videókat is készítenek a családjukról (Chaudron, 2015). A szülők az alkalmazások között említik még a tanulással kapcsolatos feladatok elvégzését, valamint a büntetést-jutalmazást és gyermekfelügyeletet (bébiszitter). A szülők nem ösztönzik kreatív eszközhasználatot (Donoso \& Ribbens, 2014). Egy hazai vizsgálat szerint az óvodáskorú gyermekek 16,3\%-a játszik online játékokkal, 26,5\%-a mobil játék-applikációkkal, 80,1\%-a néz meséket, filmeket, videókat, 38,4\%-a nézeget képeket, fotókat, 36,2\%-a hallgat zenét, 26,9\%-a színezésre, rajzolásra, festésre és $8,1 \%$-a kapcsolattartásra használja az IKT eszközöket (Hódi et al., 2019).

Az érintőképernyő-technológiák és a játékok, illetve a kisgyermekek által végzett tevékenységek internettel való összekapcsolásának köszönhetöen évről évre nő a virtuális világgal interakcióba kerülő gyermekek száma (Chaudron et al., 2015; Lauricella et al., 2015; Marsh et al., 2017). A gazda- 
ságilag fejlett országokban a 6 évesnél fiatalabb gyermekek többségének, de már a 2 éveseknek is van digitális lábnyoma (Brito \& Ramos, 2016; Holloway et al., 2013; Lips et al., 2017; Se \& Lee, 2017).

A 0-8 éves gyermekek technológiahasználata komoly aggodalommal tölti el a szülőket és a nevelésben érintett szakembereket (lásd óvópedagógusokat, pedagógusokat, védőnőket, orvosokat) (Kenney \& Gortmaker, 2016; Knowland \& Formby, 2016; O'Connor \& Fotakopoulou, 2016; Whitney \& Chapman-Novakofski 2014), legalább annyian támogatják, mint ellenzik azt, gyakran a vélt előnyökkel, mások a szintén vélt hátrányokkal érvelnek. $\mathrm{E}$ vonatkozásban ugyanis relatíve kevés az empirikus adat, és a rendelkezésre állók sem egyértelműek. Az azonban nem kétséges, hogy az IKT-használat annak paramétereitől (eszköz, tartalom, képernyőidő, mediáció) függő következményekkel jár. Ennek megértéséhez a kutatók többnyire Bronfenbrenner (1979) ökológiai fejlődésmodelljét használják. A modell és annak továbbfejlesztett változatai, számos, a mi témánkhoz is kötődő kutatásnak adnak elméleti keretet (például EuKid's Livingstone et al., 2018; Chaudron et al., 2018; Livingstone et al., 2012; Smahel et al., 2020; Thornton et al., 2013), használják olyan nemzetközi szervezetek, mint például az Egészségügyi Világszervezet, az ENSZ Gyermekalapja, az UNICEF. Jelen tanulmányban bemutatott eredmények elméleti hátteréül is a technológiai-alrendszerrel kiegészített bioökológiai modell szolgál (Johnson \& Puplampu, 2008).

\section{Bronfenbrenner ökológiai fejlódésmodellje}

Az elmélet alapfeltevése, hogy az egyén egymást átfedő ökológiai rendszerekben él, a fejlődést az egyén és a kontextus kölcsönhatása, az egyén környezetében zajló folyamatok, az ökológiai rendszerek belső és szomszédos rendszerek közötti kapcsolatai, az egyén és környezete közötti interakciók határozzák meg. Bronfenbrenner eredetileg (1977, 1979) négy egymásba ágyazadó, egymásra kölcsönösen ható ökológiai rendszert (mikro-, mezo-, exo-, makroszisztémát) azonosított, melyet később az idő dimenzióval egészített ki (Bronfenbrenner, 1994).

A mikroszisztéma a fejlődő egyén közvetlen környezetében (például a családban, óvodában, közvetlen lakókörnyezetben) zajló tevékenységek, szerepek, interperszonális kapcsolatok rendszere. Ez kora-, és kisgyermekkorban főleg családi, kortársi és nevelői/gondozói interakciókat jelent. Például egy óvodáskorú gyermek mikroszisztémjának elsődleges és leginkább meghatározó elemei kapcsolatai a családtagokkal, szülőkkel, testvérekkel, nagyszülőkkel. De részei lehetnek az óvónőkkel, az óvodai kortársakkal megvalósuló interakciók is. Az egyén (gyermek) egymással kapcsolatban, kölcsönhatásban levő, mikroszisztémáiának rendszere mezoszisztéma. Olyan tevékenységek, interakciók, amelyekben a fejlődő egyén (gyermek) aktív szereplő, amelyek befolyásolják az ő mikroszisztémáját, annak történéseit (Bronfenbrenner, 1979, p. 25). Ilyenek például szülők és testvérek baráti kapcsolatai, 
szomszédok, az egyik mikroszisztéma tudása, attitűdje a másikról. Az ökológiai rendszer következő szintje a mezoszisztémák kiterjesztése, az exoszisztéma. Ezek formális és informális társadalmi struktúrák, amelyekben a fejlődő egyén (gyermek) már nem aktív szereplő, de azok közvetetten, a mezoszisztémán keresztül befolyásolják az ő közvetlen mikrokörnyezetét, annak történéseit (Bronfenbrenner, 1979, p. 25). Ilyenek például szülők munkahelye és baráti kapcsolatai, a testvérek osztálytársai, a szomszédok, az iskolaszék, a különböző kommunikációs rendszerek. Az elmélet szerint az adott személy életét alakító összefüggéseket leképező mikro-, mezo- és exoszisztémák a makroszisztémában léteznek. A makroszisztémát az egyén, a család társadalmi, gazdasági státusza, az adott kultúra, szubkultúra szokásai, értékekei, hiedelmei, ideológiái, társadalmi, politikai, gazdasági, oktatási stb. struktúrái határozzák meg. Mivel a fejlődés döntő tényezője az idő, a továbbfejlesztett verzió figyelembe veszi a rendszerek, az egyén és a környezet kölcsönhatásainak változásait (például a lakóhely átalakulásának, a szülők válásának, egy új közösségbe kerülés hosszútávú hatásait), és a teljes ökoszisztémát az idő dimenziójába, a kronoszisztémába helyezi (Bronfenbrenner, 1989).

$\mathrm{Az}$ infokommunikációs forradalmat követően egyes hatásvizsgálatokban a mikroszisztémában megjelent a technológia-alrendszer, mutatva annak a gyermekekkel és a mikroszisztémával való kétirányú kölcsönhatását. „...a technológia-alrendszer magában foglalja a gyerekek interakcióját a kommunikáció élő (például társak) és élettelen (például hardverek) elemeivel, az információs és rekreációs technológiákkal." (Johnson \& Puplampu, 2008, p. 5). Így értelmezhetővé váltak a gyermekek napi gyakorlatát meghatározó közvetlen és közvetett környezet összefüggései, a szülők közvetítő stílusának sokszínűsége.

Bronfenbrenner (1979) az egyre komplexebb ökológiai struktúrákat koncentrikusan egymásba ágyazódó rendszerként képzeli el. Az elmélet grafikus ábrázolása az azt alkalmazó kutatók nevéhez füződik. Ebből adódóan azok az aktuális kutatási kérdéseknek megfelelően részleteikben különbözőek (Boon et al., 2012; Chaudron et al., 2018; Eisenmannet al., 2008; European Agency, 2016, p. 15; Gromek, 2018; Halpern \& Figueiras, 2004; Johnson, 2010; Johnson \& Puplampu, 2008; Pen, 2005; Tudge, 2008; Vélez-Agosto et al., 2017).

Mint az a bioökológiai fejlődésmodellből is következik a kisgyermekek technológiahasználatának megértéséhez, optimális és hatékony támogatásához az IKT-tevékenység paraméterein (eszköz, tartalom, képernyőidő) és hatásain túl ismerni kell a kontextust, az azokat alakító komponenseket és azok kapcsolatait is. Ez pedig 0-6 éves korban az elsődleges moderáló tényező, a kulcsszereplő szülő infokommunikációs technológiát közvetítő „kapuőr” viselkedését meghatározó tényezők feltárását jelenti. Kutatások szerint a mediáció módja/stílusa összefügg a szülök értékeivel, percepcióival, a digitális médiához való viszonyulásával, motivációjával, attitűdjeivel, az IKT-tevékenységek során szerzett tapasztalataival, magabiztosságával (Chaudron et al., 2015; Chaudron et al., 2018, p. 52; Clark, 2011; Rideout \& Hamel, 2006). 


\section{Szülök viszonya a gyermekek IKT-használatához}

A szülők gyermekük IKT-használatával kapcsolatos érzései ambivalensek. Alapvetően pozitívan viszonyulnak ahhoz, mert szórakozást, elfoglaltságot kínál, „babaőrként” szolgál, emellett a kisgyermekkori fejlesztés egyik eszközét látják benne (Chaudron et al., 2018; Kabali et al., 2015; Seo \& Lee, 2017). Ugyanakkor bizonyos alkalmakkor (például étkezés közben) sokan korlátozzák az okoseszközök használatát, tartva attól, hogy az elszigeteli a családtagokat (Donoso \& Ribbens, 2014).

Sokan látják a digitális tevékenység egyik legfontosabb hozamát a tanulásban, a tudásszerzésben (pl. nyelvtanulás, számképek megtanulása (Chaudron et al. 2015; Donoso \& Ribbens, 2014; Papadakis et al., 2019; Plowman et al., 2010). Számos kutatás mutatott rá arra, hogy a szülők a korai IKT-használatot befektetésnek tekintik, amellyel megalapozható a gyermekek iskolai, szakmai jövője (Brito \& Dias, 2016; Plowman \& McPake, 2013), előnyhöz juttatja őket az intellektuális és szociális fejlődésben (Jabbar et al., 2019). Vannak azonban, akik azon az állásponton vannak, hogy az IKT korai használata nem előny annak gyors változása miatt, az óvodás korban megtanultak elavulnak mire a gyermekek iskolába kerülnek (Plowman \& McPake, 2013). Sokan alábecsülik gyermekük digitális műveltségét, úgy gondolják, hogy a 0-8 évesek nem képesek önállóan használni a technológiát és még nem érdekli őket az internet (Brito \& Ramos, 2016; Donoso \& Ribbens, 2014; Plowman et al., 2010).

Több vizsgálat megállapította (Donoso \& Ribbens, 2014; Seo \& Lee, 2017), hogy bár a tanulást ösztönző környezet kialakítására törekvő szülők hajlamosak alábecsülni a kockázatokat, pontosabban fogalmazzák meg azokat, mint a pozitívumokat. A különböző országokban élő kisgyermekes szülők félelmei hasonlók, és főként a technológiahasználat pszichológiai, kognitív, fizika (testi), szocioalizációs hatásai miatt aggódnak (O’Connor \& Fotakopolou, 2016; Plowman et al., 2010; Seo \& Lee, 2017).

Az IKT-használat leggyakrabban említett nemkívánt hatása mind a szülők, mind a szakemberek részéről az addikció és a túlzott, illetve nem megfelelő használat (Donoso \& Ribbens, 2014). Gyakori félelem, hogy a gyermekek előnyben részestik a technológiát, és a digitális tevékenységek kiszorítják a hagyományos játékokat, elvonják a gyermekeket más értékes társas és fizikai (valós) tevékenységektől (Bakó \& Ráb, 2009; Bálint et al., 2020). Plowman, McPake és Stephen (2010) kutatásában a szülők a technológiát tették felelőssé azért, hogy a gyermekek nem olvasnak könyveket, miáltal gátolja a nyelvi fejlődést.

Az óvodáskorú (3-5 év közötti) gyermekek szüleinek félelemei gyakran a gyermekek egészségével kapcsolatosak (Barreto \& Adams, 2011), főként a lehetséges negatív testi (például látás romlása, elhízás), pszichoszociális vagy kognitív elváltozásokra irányulnak (Chaudron et al., 2018). Sokan tartanak aszociális viselkedés (például függőség, agresszió, szorongás, rivalizálás), 
nemkívánt attitűdök kialakulásától, illetve megerősítésétől (Horst, 2010; Donoso \& Ribbens 2014; Kucirkova \& Littleton, 2016; Matsumoto et al., 2016; Plowman et al., 2010).

Jelen tanulmány a szülők „kapuőr” viselkedését alakító komponensek közül kettőt, a médiatevékenység hatásairól alkotott véleményét, valamint az IKT-hoz való viszonyulását, preferenciáit mutatja be. Mivel a forrásként szolgáló kutatások többségében néhány tíz, hasonló demográfiai jellemzőkkel bíró család vett részt, így azok egy szúk, speciális csoport percepcióira mutatnak rá. Tanulmányunk ellenben egy, az óvodáskorú gyermekek otthoni digitális környezetét, a gyermekek és szüleik IKT-eszköz használatát vizsgáló, nagymintás kutatás célzottan e témában gyüjtött adatait dolgozza fel (lásd Hódi et al., 2019). Az „IKT eszközök használata óvodás korban” című kérdőív felvétele kérdőíves vizsgálatokban szokásos módon történt, a szülők mindenféle előzetes instrukció, beszélgetés, mindennemü, a gondolataikat esetlegesen orientáló körülmény nélkül ad hoc fogalmazták meg véleményüket. Így feltételezhetjük, hogy a kapott válaszok azt tükrözik, ami először eszükbe jutott a témáról, ami leginkább foglalkoztatja őket e témában, amit leginkább a technológiahasználat pozitív, illetve negatív következményének tartanak.

\section{A kutatáscélja, kérdései}

A kutatás célja kvalitatív feltárás, elméletépítés volt, azoknak a nyitott kérdésekre kapott szülői vélekedéseknek szakirodalmi megállapításoktól független azonosítása, amelyek meghatározzák óvodáskorú gyermekük IKT-használatát mediáló viselkedésüket. Kutatási kérdéseink a következők:

- Milyen kedvező, pozitív hatásokat tulajdonítanak a szülők a gyermekek IKT-használatának óvodás korban?

- Milyen nemkívánt (negatív) következményekkel jár a szülők szerint az óvodáskorú gyermekek IKT-használata a gyerekekre nézve egyéni szinten?

- Milyen, a nevelés számára releváns kategóriákat alkotnak a válaszok?

A környezeti (mezo- és magasabb szintü) hatásokat egyik kérdés esetében sem vizsgáltuk.

\section{Eszközök és módszerek}

\section{Méröeszköz}

Az „IKT eszközök használata óvodás korban” projekt céljának megvalósítása, az óvodáskorú gyermek otthoni technológia-fogyasztásának és ható tényezőinek vizsgálata egy 65 itemes papír alapú kérdőívvel történt (Részletesen lásd Hódi et al., 2019). A kérdőív a gyermekek mikrokörnyezetének, a család IKT eszközeinek, az eszközhasználat (gyermek és szülő) paramé- 
tereinek (tartalomfogyasztás, képernyőidő, szülői kontroll) feltárását célzó egységében kapott helyet a szülők gyermekek digitális IKT-használatának hatásaival kapcsolatos nézeteire vonatkozó két kérdés: Ön szerint milyen pozitív (jótékony), illetve negatív (káros) hatása lehet az IKT-eszközök használatának óvodás korban? Kérem, fejtse ki véleményét!

\section{A kutatás résztvevői}

A kutatásban egy nagyváros, mint kultúrahordozó egység önkormányzati fenntartású 43 óvodájába járó valamennyi, összesen 3969 gyermek szülei vettek részt. A kitöltések száma 1881 volt, ami a vizsgált populáció 47,39\%áról nyújt adatokat (a részletes leírást lásd Hódi et al., 2019). A feldolgozott kérdőívekben a technológia pozitív hatásairól a szülők 78,5\%-a (teljes minta 37,97\%-a, 1507 fó), a negatív hatásokról 82,14\%-a (a teljes minta 38,93\%-a 1545 fö) fejtette ki véleményét. Nézeteiket döntő többségében nők fogalmazták meg, mindössze két férfi volt a válaszadók között.

\section{Adatgyüjtés, az elemzés módszerei}

Az adatfelvételre 2018 április-május hónapokban került sor a fenntartó engedélyével. A kérdőíveket személyesen vittük el a tagintézmények vezetőinek, írásban és szóban tájékoztattuk őket a kutatás céljáról, folyamatáról. Az adatfelvételt az intézmények munkatársai, jellemzően a csoportvezető óvónők végezték. Ök juttatták el a kérdőíveket valamennyi gyermek családjához, majd gyüjtötték be azokat. A kérdőív kitöltése 20-25 percet vett igénybe, a válaszadás önkéntes és anonim volt.

A szülők véleményének kódolását a megalapozott elmélet (grounded theory, Strauss \& Corbin, 1994) módszertani útmutatásait követve a Charmaz (2003) féle konstruktivista megközelítésben végeztük. A kódolás technikailag az általunk fejlesztett Microsoft Excel programban futó EKOD makró segítette.

\section{Eredmények}

Vizsgálatunkban a szülők az „Ön szerint milyen pozitív (jótékony), illetve negatív (káros) hatása lehet az IKT-eszközök használatának óvodás korban?” kérdésekre változó komplexitású válaszokat adtak. Többnyire egy, kettő és néha három, ritkán négy, egymással nem feltétlenül egy gondolati egységet alkotó állításban fogalmazták meg véleményüket. Ezért egy-egy kitöltés több válaszkategóriában is szerepel, amiből következik, hogy a kódolt válaszok száma nagyobb, mint a kitöltéseké, így a gyakoriságok összege nem 100\%. (A kategorizálás során felmerült problémákat lásd B. Némett et al., 2019.)

\section{Szülök véleménye az IKT-használat pozitív hatásairól}

Az IKT-tevékenység pozitív hatásairól kapott szülői vélemények többsége az IKT fejlesztő, tanulást támogató, információszerző jelentőségét emeli ki, de 
említik még a „technologizált világ megismerését, a kapcsolatépíto és -tartó, szórakoztató" szerepét is. Kutatásunkban az oktatáshoz, tanuláshoz kapcsolódó válaszokat a tágabb értelmezést adó „Tudásépítés” kategóriafogalom alá soroljuk. (1. táblázat) Ez lehetővé teszi az IKT-használat egyik megatározó momentumának, a játék, zene, mese, videó, információ stb. elérésének, megismerésének elkülönítését a fejlesztő hatástól és a tanulástól.

Adataink szerint az infokommunikációs technológiák pozitív hatásait a szülők döntő többsége, 86,79\%-a (1308 fö), a tudásszerzéssel, a tudáshoz, információhoz való hozzáféréssel kapcsolja össze. (1. táblázat) A válaszok több, mint egyharmadában szerepelnek a „tanul / tanulás” szavak (496 fö; $32,91 \%$ ), illetve a „fejleszt / fejlődik / fejlesztő" (574 fö, 38,09\%), utalva a tudáshoz/ismeretekhez való hozzáférésre. A vélemények 15,79\%-ában (238fö) vannak jelen az „információ-/ismeretforrás, -gyüjtés, -szerzés” kifejezések.

\section{1. táblázat}

Az „Ön szerint milyen pozitív (jótékony) hatása lehet az IKT-eszközök használatának óvodás korban?" kérdésre adott válaszok gyakorisága (az összes kitöltés száma: 1507)

\begin{tabular}{|c|c|c|c|c|c|}
\hline \multirow{2}{*}{\multicolumn{2}{|c|}{$\begin{array}{l}\text { Válaszkategóriák } \\
\text { száma }\end{array}$}} & \multicolumn{4}{|c|}{ Válaszok } \\
\hline & & \multirow{2}{*}{$\begin{array}{c}\begin{array}{c}\text { aránya } \\
(\%)\end{array} \\
496\end{array}$} & \multirow{2}{*}{$\begin{array}{l}\text { száma } \\
32,91\end{array}$} & \multirow{2}{*}{$\begin{array}{c}\begin{array}{c}\text { aránya } \\
(\%)\end{array} \\
1308\end{array}$} & \multirow[b]{2}{*}{86,79} \\
\hline \multirow{3}{*}{ Tudásépítés } & Tanít & & & & \\
\hline & Fejleszt & 574 & 38,09 & & \\
\hline & $\begin{array}{l}\text { Ismeretet, információt } \\
\text { szolgáltat }\end{array}$ & 238 & 15,79 & & \\
\hline \multirow{2}{*}{ Technologizált világ } & Jövőbe mutat & 68 & 4,51 & \multirow[t]{2}{*}{337} & \multirow[t]{2}{*}{22,36} \\
\hline & Használja a technológiát & 269 & 17,85 & & \\
\hline Leköt, szórakoztat & & & & 81 & 5,37 \\
\hline \multicolumn{2}{|c|}{ Interperszonális kapcsolatépítés, -tartás } & & & 43 & 2,85 \\
\hline Nincs pozitív hatás & & & & 182 & 12,08 \\
\hline \multicolumn{2}{|c|}{ A szülő nem tud / nem ismer pozitív hatást } & & & 35 & 2,32 \\
\hline \multirow{3}{*}{ A szülő IKT-attitűdje } & Szükséges, ez a jelen & 92 & 6,10 & & \\
\hline & Elutasító & 63 & 4,18 & 193 & 12,74 \\
\hline & Kontrolláló / mediáló & 37 & 2,46 & & \\
\hline
\end{tabular}

A válaszadók közel egyharmada (496 fö; 32,91\%) gondolja, hogy az infokommunikációs technológia használata jó alkalom a tanulásra. 101 szülő $(6,70 \%)$ szerint az IKT-tevékenység gyarapítja az ismereteket, a gyermekek meséket, dalokat, mondókákat tanulnak, megismerkednek a színekkel, a számokkal, a betűkkel stb., 126-an (8,36\%) vélik, hogy az IKT-használat növeli a szókincset és támogatja a nyelvtanulást. 
„Ha a korosztályának megfelelő programot használja, tanul belőle.”

„Ha a szülő odafigyel rá, a gyermek tanulhat is belőle."

„Angol mesék nézésével fejleszti a nyelvtudását."

„Ha fejlesztő programokat vagy idegen nyelvüt használ, abból tanulhat, ügyesedhet."

„Szülői vagy tanári felügyelettel az internet segítségével sok érdekességet, ismeretet tudnak elérni."

A szülők 8,82\%-a (133 fö) megnevezett fejlesztő hatásúnak tartott konkrét tartalmakat, programokat/szoftvereket, melyek legtöbbször elektronikus játékok (96 fó; 6,37\%), de felbukkan még a mese (17 fö; 1,13\%), a zenehallgatás, és „matematikafeladatok megoldása” is. Az összes válasz csaknem egy negyede, 24,02\%-a (362 fö) kitér a hatás vélt következményére, melyek között vannak kognitív és pszichomotoros területek is. Eszerint az eszközhasználat fejleszt készségeket/képességeket (89 fö; 5,91\%), gondolkodást (90fö; 5,97\%), kézügyességet, a koordinációt, finommozgásokat, reflexeket (65fö, 4,31\%). De jótékony hatással van a kreativitásra (27 fö; 1,79\%), a figyelemre/koncentrációra (45fö; 2,99\%), a memóriára (20 fö; 1,33\%). Néhány szülő említi még a kompetenciát, a fantáziát, a kommunikációt, a ritmusérzéket, és a türelmet (összesen 26 fö; 1,73\%) is.

„Fejlesztő hatása lehet a jól megválasztott programoknak."

„Fejlesztő, például memóriajáték.”

„Bizonyos játékok fejleszthetik a készségeit.”

„Fejlesztő hatású lehet: játékok, zenehallgatás."

15,79\% (238 fő) azoknak a válaszoknak az aránya, amelyek pozitívan értékelik az információ, az ismeretek gyors és könnyü megszerzésének lehetőségét a különböző dolgok, a másképpen nem megnézhető, megmutatható dolgok elérésében.

„Sok olyan dologgal megismerkedhet, amit lehet, hogy személyesen nem tud megtapasztalni."

„Önállóan új ismereteket gyűjt.”

„Instant élményszerzés, bizonyos vágyak gyors/egyszerü kielégítése.”

„Olyan információkat tud meg, amit én, mint szülő nem tudok.”

A vélemények második nagyobb csoportjába tartozó válaszok, melyet a "Technologizált világ" (337 fö; 22,36\%) címkével jelöltünk, arra utalnak, hogy a szülők egy csoportja a digitális médiát korunk elengedhetetlen részének tekinti, amely nem feltétlenül pozitív, de használatát jobb mielőbb megtanulni. A szülők esetünkben is megfogalmaztak olyan más kutatási beszámolókban (például Brito \& Dias, 2016; Plowman \& McPake, 2013) is fellelhető vélekedéseket, miszerint a korai technológiahasználat, megkönnyíti a gyermekek későbbi boldogulá- 
sát, megalapozza az iskolai tanulmányukat. A válaszadók 65\%-a (4,31fó) szerint jó, ha gyermekük már óvodás korban megismerkedik az infokommunikációs technológiával, mivel később úgyis találkozni fog azokkal, használnia kell azokat. Ezt a csoportot Matsumoto és munkatársai (2016. p. 46) ${ }^{2}$ alapján a „J̈vő́be mutat" kifejezéssel jelöltük. 269 szülő (17,85\%) az IKT-használat elsajátítását nevezi meg mint hasznos következményt. Annak előnyét a technológia kezelésének, a program- és az internethasználat korai, játékos elsajátításában látja. Megneveznek olyan, egyébként hagyományosan, az infokommunikációs forradalom előtt is végzett tevékenységeket, mint a mesék, dalok, mondókák, zene hallgatása, fényképek és videófilmek nézése, szemléltetés . Ilyenkor az IKT nem más mint közvetítő eszköz).

„A mai világ ezeknek az eszközöknek a használatára épül, ilyen módon hamarabb el tudják sajátítani a használatukat, kezelésüket."

„Később nem okoz majd problémát neki a használata."

„Később nagy hasznát veszi az iskolában.”

„Megtanulja, hogy kell azokat használni.”

„Gyakran hallgatunk mondókákat, dalokat (például Kerekmese).”

Nem tipikus, de jelen vizsgálatban is megjelenik az IKT-tevékenység szülők által pozitívan értékelt jellemzőjeként (lásd még például Chaudronet al., 2018; Cingel \& Krcmar, 2013; Kabali et al., 2015), hogy az szórakoztatja, leköti a gyermekeket (81 fö; 5,37\%), valamint könnyíti a családtagokkal való kapcsolattartást (43 fö; 2,85\%).

„Utazással, várakozással járó élethelyzetekben segítséget nyújt.”

„Leköti a figyelmét, ha szükség van rá (fözök, takarítok, ...)."

„A megfelelő tartalom használata során kikapcsolódás."

„Kapcsolatot tud tartani a távoli rokonokkal, barátokkal.”

A szülők 12,08\%-a (182 fö) mondta azt, hogy szerinte gyermekük eszközhasználatának nincs semmilyen jótékony hatása, és 2,32\%-a (35fö) pedig nem tud ilyenekről.

„Óvodás korban szerintem nem ezekkel kell játszania, nem tudok pozitívumot mondani."

„Nincs pozitív hatása kisgyermekkorban.”

„Nem tudnék olyan pozitív dolgot, amit más módon ne lehetne megtanítani.”

A szülők egy népesebb csoportja (192 fö; 12,74\%) az IKT-használat pozitív hatása helyett az ahhoz való viszonyát fogalmazta meg. A válaszok három csoportba sorolhatók. Mint néhány fent idézett véleményből is kitünik, van-

\footnotetext{
${ }^{2}$ Matsumoto és munkatársai (2016) spanyol szülők körében végzett kutatásában oktatás, munka és társadalom kategóriákat azonosítottak.
} 
nak szülők, akik szerint az IKT-tevékenység életünk részévé vált, és a kisgyermekeknek is szükséges megismerni, használni az infokommunikációs technológia eszközeit. 6,10\% (92 fö) véli, hogy az IKT-használat szükséges függetlenül attól, hogy hatása pozitív vagy negatív. A válaszadók 4,18\%-a (63 fó) az ellenkezőjét gondolja, korainak tartja azt óvodás korban, 2,46\%-a (37 fö) pedig csak az ellenőrzést emeli ki.

„A mai világban szükség van az informatikai ismeretekre, DE nem 3 éves korban." „Nem tartom indokoltnak, hogy ilyen idős korban már napi kapcsolatban legyen ezen eszközökkel."

„Nagyon korlátozott anyagot adok neki, például madárfészkeket nézünk webkamerán."

\section{Mit gondolnak a szülök az IKT-használat negatív hatásairól}

$\mathrm{Az}$ „Ön szerint milyen negatív hatása lehet az IKT-eszközök használatának óvodás korban?" kérdésre adott válaszok többségében négy rizikófaktor fedezhető fel. (2. táblázat) A (1) nemkívánt tartalom és (2) viselkedés, (3) a szülő által fontosnak tartott tevékenységek (például mozgás, társasjáték stb.) elutasítása, a kiszorítás és a (4) zavar, a gyermek testi egészségének, szocializációs, kognitív és pszichés folyamatainak, fejlődésének nemkívánt megváltozása. - A „zavar” kifejezés köznapi tartalmakat takar, nem orvosi, pszichológiai értelemben vett kóros elváltozásokat. Lényege, hogy az IKT használata megzavarja a megnevezett sajátságok válaszadó szerint normálisnak tartott működését, fejlődését.

A szülők leginkább az IKT-tevékenység gyermekeik magatartásában, napi foglalatosságainak változásában megnyilvánuló következményeit észlelik. Érthető, hogy legtöbben a viselkedést szerintük rossz irányba terelő hatásokat, a nemkívánt viselkedésformák megjelenését, illetve a fontosnak tartott tevékenységek háttérbe szorítását említik. A szülők közel kétharmada (977 fö; 63,24\%) az IKT gyermekek mindennapjaiba való beépülésének veszélyét valamilyen nemkívánt viselkedésben látja. Legtöbben, 751-gyen (48,61\%) a függővé válás miatt aggódnak. Vannak, akik szerint az IKT-tevékenység nyugtalanító velejárója, hogy a gyermekek agresszívvé, erőszakossá, ingerlékenyé és hisztissé válhatnak, türelmetlenek lesznek és a szenzoros túlterhelés miatt eseténként olyan viselkedésminták jelenhetnek meg, mint például „túlpörgés".

„Könnyen rászoknak a gyerekek és nem akarnak mást csinálni.”

„Gyorsan beszippantja a gyerekeket, szigorú korlátok szükségesek."

„Túl sok inger éri, ha túl sok időt tölt ilyen eszközökkel.”

„Az elvonás után a gyermek agresszívabb, pszichésen instabilabb lesz."

„Túlzottan felpörgeti, ha nagyon sok az inger, nehezen dolgozza fel.” 
Szülők véleménye az óvodáskorú gyermekek IKT-eszköz használatának

2. táblázat

$A z$ „Ön szerint milyen negatív (káros) hatása lehet az IKT-eszközök használatának óvodás korban?” kérdésre adott válaszok gyakorisága (kitöltések száma: 1545)

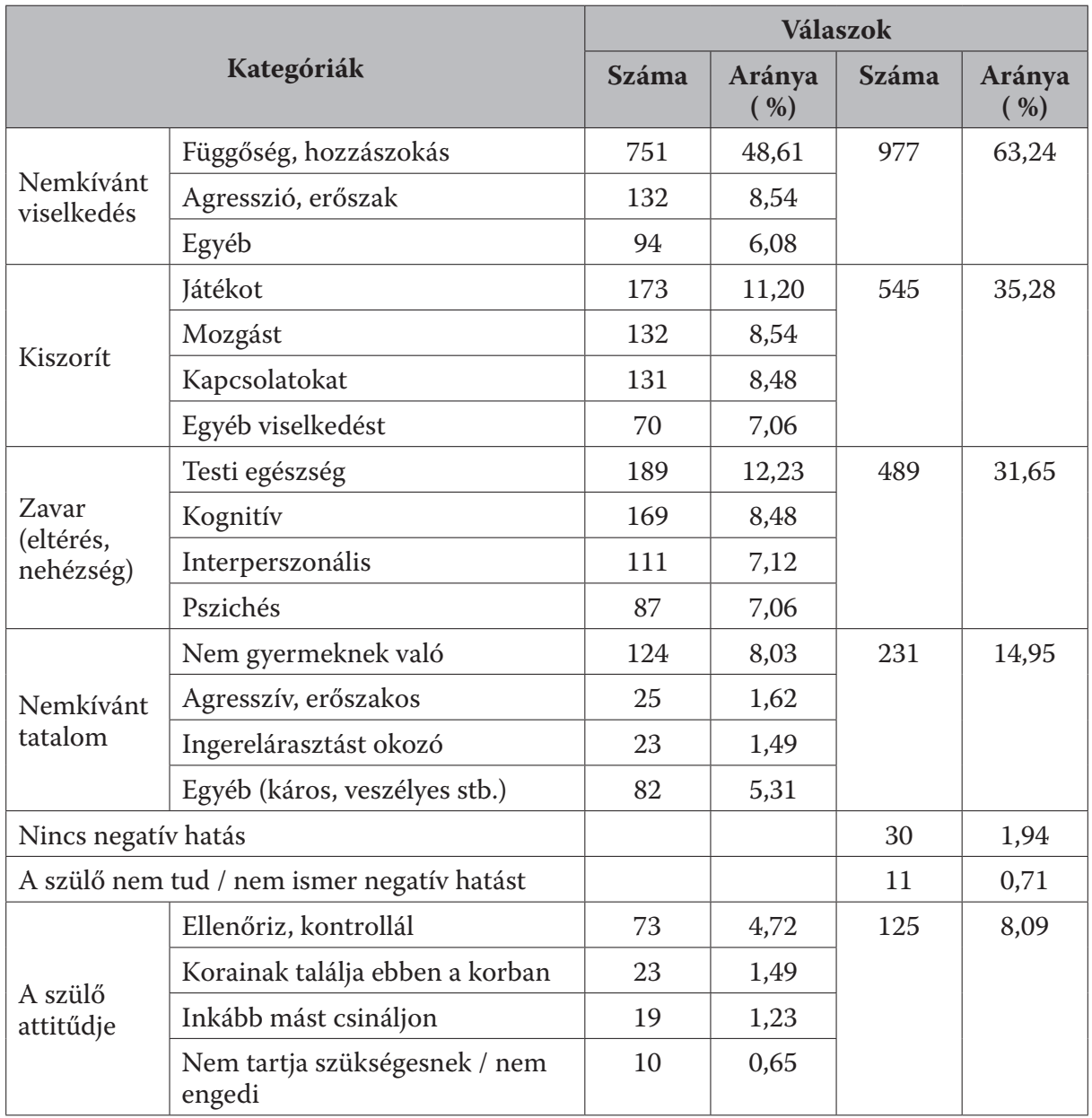

Egy spanyol, kisgyermekes szülők körében végzett vizsgálat eredményeihez hasonlóan (Chaudron et al., 2018), az általunk megkérdezettek is jelentős számban azt érzékelik, hogy versenyeznek egymással az infokommunikációs technológia és a kisgyermekek hagyományos tevékenységei. Az addikció után a második leggyakoribb álláspont, az összes válaszadó több, mint egy harmada (545 fö; 35,28\%) véli, hogy az infokommunikációs technológia elvonja a gyermekeket más fontosnak tartott időtöltésektől. Negatív hatásként legtöbben, 173 fö $(11,20 \%)$ a fizikai, személyes jelenlétet, részvételt 
igénylő, a szabadban és társakkal való játék gyakoriságának, időtartamának csökkenését nevezik meg. Mások szerint (132fö; 8,54\%) nem jó, hogy a IKThasználatnak köszönhetően a gyermekek ritkábban és kevesebbet mozognak, ellustulnak. Csaknem ugyanennyien (131 fö; 8,48\%) vélik ártalmasnak a gyerekek társakkal, családdal való közös tevékenységektől való távolmaradását. Néhány válaszadó (25 fő;1,62\%) szerint a technológiafogyasztás káros következménye a külvilág kizárása, a befelé fordulás.

„Nem szeretne hagyományos játékokkal játszani.”

„Elvonja a gyereket a kreatív, szabad játéktól.”

„A testmozgás és a szabad levegőn való játék rovására mehet."

„Az óvodáskorú gyermeknek az egymással való kommunikáció és a mozgás a

legfontosabb, ebben gátolják az IKT-eszközök."

Kutatásunkban a harmadik leggyakoribb vélekedés, az összes kitöltés több, mint egyharmadában jelenik meg (539 fö; 34,9\%), hogy az IKT-tevékenység óvodás korban testi, mentális, szocializációs, fejlődési nehézségeket, zavart okoz. A szülők (189 fö;12,23\%) aggódnak azért, hogy a „sok használat", a nem megfelelő képernyőidő egészségkárosodáshoz vezet. Vannak, akik szem-, illetve látáskárosodástól tartanak (139 fö; 9,00\%), mások szerint kialakulhatnak mozgásszervi elváltozások (gerincproblémák, tartáshibák), illetve fennáll az elhízás, az idegrendszeri fejlődés problémájának veszélye.

„Káros a szemére, elfelejt pislogni, meredten nézi a képernyőt.”

„Gerincferdülés alakulhat ki.”

„Hosszú távon az idegrendszer túlterhelése.”

A szülők egy része (131 fö; 8,48\%) kognitív zavarok megjelenésében látja a technológiahasználat kockázatát. Közülük 55-en (3,56\%) gondolják, hogy az IKT szegényesebbé teszi a gyermekek fantáziáját, képzeletét. Mások szerint csökkenti a kreativitást (42 fó; $2,72 \%$ ) vagy éppen akadályozza a gyermekeket a gondolkodásban (20 fö;1,29\%).

„A fantázia, kreativitás nem fejlődik a készen kapott információk miatt.”

„A gondolkodás és képzelet világának megfelelő fejlődése visszamaradhat."

„Nem használja az eszét és nem gondolkodik, mert a gép megadja a válaszokat helyette."

„Az állandó-azonnali válaszreakció rontja a figyelem minőségét."

„Amennyiben az az egyetlen kikapcsolódás, játék beszükíti a gyermek figyelmét, érdeklődési körét."

„Szétszórja a gyermek figyelmét, de közben rögzíti is a monitorhoz." 
110 szülő $(7,12 \%)$ véli, hogy az IKT-tevékenység nem kedvez az interperszonális kapcsolatoknak, visszaveti a gyermekek szocializációját, csökkenti és szegényesebbé teszi a személyes kommunikációját.

„Személyes kommunikáció (beszélgetés, közös játék) hiánya."

„Nem tesz jó hatást a kommunikációra, kapcsolatteremtő készségre, szociális kapcsolatokra."

„A számítógépes játékokat a közösségi szocializációra és az érzelmi intelligencia fejlődésére nagyon kártékonynak tartom."

Valamivel kevesebben vannak (87 fö; 7,06\%), akik az IKT-használat pszichés következményeitől, alvászavar, félelem, szorongás kialakulásától tartanak. Néhányan (22fö; 1,42\%) realitásfunkciók elvesztése, a valóságtól való elszakadás miatt nyugtalankodnak. Szerintük az IKT-tevékenység veszélye, hogy az óvodáskorú gyermekek nem tudják elkülöníteni a valós és a virtuális világot.

„Az eszköz használatát követően nehezebben alszik el.”

"Csökken a valós helyzetek felmérése és problémamegoldó készség."

„Nem tudják szürni az információkat, valós és igaz információnak tűnik számukra minden."

„Teljesen az eszközök világában élnek és később sem a valóságban csak egy virtuális világban léteznek."

„Nem megfelelő oldalak, képek, videók megtekintése félelmet kelt.”

„A 3-4 éves gyerek még nincs tisztában a valóság és az internet közötti különbséggel."

„Elszakad a valóságtól, nem érti meg az őt körülvevő világot.”

„Szoronghatnak, ha például nekik nincs letöltve egy játék, ami a másiknak megvan, nem tud hozzászólni, ha arról beszélnek a gyerekek, kirekesztve érezheti magát."

Vizsgálatunkban a szülők véleményének tartalomelemzésével azonosított negyedik rizikócsoportja a használt és a potenciálisan elérhető médiatartalom. 231 válaszadó $(14,95 \%)$ véli, hogy az infokommunikációs technológia veszélyét az agresszív, erőszakos, buta, nem óvodáskorú gyerekeknek való tartalmú videók, játékok, az online jelenlét alatt megjelenő nemkívánt weboldalak, hirdetések jelentik.

„Sok olyan tartalmat nyithat meg, ami nem neki való."

„Könnyen eléri az internetet, amin sok az erőszak, illetve erőszakos játékok vannak."

„Rengeteg az értelmetlen és butító videó."

„Negatív, káros, nem az életkoruknak megfelelő hirdetések."

„Reklámok, nem gyermeknek való tartalmak hozzáférhetősége.” 
Az IKT-használat veszélyei kapcsán hasonlóan, mint az előnyök esetében vannak szülők, bár jóval kevesebben, akik szerint nem kell negatív következménytől tartani (30 fö;1,98\%), illetve nem tudnak ilyenről (46 fö; 2,98\%a). Tizenegyen csak annyit írtak, hogy „Nincs.” vagy „Szerintem nincs.” 19 válaszadó pedig azért véli, hogy gyermeke IKT-tevékenysége nem jár káros következménnyel, mert azt ellenőrzés, felügyelet mellett teszi.

„Felügyelettel, gondosan kiválasztott tartalommal nincs [káros hatása].”

„Szerintem nincs káros hatása, ha megfelelö oldalakat néz."

„Esetünkben nem jellemző, mert korlátozott, ellenőrzött, reklámmentes alkalmazásokat használ."

„Nem feltétlenül kell, hogy negatív hatása legyen, tudni kell a határokat, sajnos ez a jövo"."

„Nem érzem, hogy lenne negatív hatása, ha ellenőrzöm, hogy mit csinál rajt.” „Kis mennyiségben integrálva nem lenne káros."

Mint az néhány idézett válaszban felfedezhető a válaszok egy csoportja ugyanúgy, mint a pozitív hatások esetében nem az IKT hatásairól szól, hanem a szülő digitális médiához való viszonyulását mutatja (125 fö; 8,09\%). A többségben (73 fö; 4,72\%) az odafigyelés, az ellenőrzés, a tartalomszürés, az eszközhasználat korlátozásának szükségességége szerepel. 52 vélemény (3,37\%) pedig az IKT-tevékenység elutasításáról tanúskodik. De van olyan álláspont is, amely szerint a digitális média nem óvodáskorú gyermekeknek való, illetve mit kellene tenniük a gyermekeknek ahelyett, hogy ezekkel a „kütyükkel” foglalják el magukat. A vélemények között megtalálható az IKThasználatának elutasítása, néhány szülő szükségtelennek tartja és nem is engedi meg azt gyermekének.

„A tartalomszürés teljes hiánya borzasztó káros lehet."

„Nem szabad engedni, hogy felügyelet nélkül használja."

„Korlátozás, kontroll nélkül csak ezzel foglalkozna.”

„Kicsik ehhez, bármennyire szürhető a tartalom.”

„Káros, ha mindig valamilyen kütyü van a kezében, de nálunk ez nem áll fent.”

„Szerintem a számítógépes játékokra semmi szükség."

\section{Diszkusszió}

Jelen kutatásban óvodáskorú gyermekek szüleit kérdeztük gyermekük IKThasználatának következményeiről. Válaszaikban a szülők percepcióikat és attitűdjeiket, esetenként mindkettőt fogalmazták meg. (3. táblázat) Vizsgálatunkban az infokommunikációs technológia jótékony hatását a szülők jellemzően a tudás megszerzésében, a fejlődés és a tanulás lehetőségében, illetve az információhoz való hozzáférésben látják. A megkérdezettek néhány korábbi kutatással összhangban úgy gondolják, hogy a korán megkez- 
dett IKT-tevékenység előnyt jelent a jövőben, e tapasztalatok előkészítik a későbbi tanulmányokat és a gyermekeknek könnyebb lesz az iskolában. Válaszadóink között is vannak, akik ugyanúgy, mint másutt a világban (lásd például Cingel \& Krcmar, 2013; Kabali et al., 2015; Seo \& Lee, 2017), pozitívan értékelik, hogy a digitális média szórakoztatja, leköti a gyermekeket, mikor elfoglaltak, sok a munkájuk.

Az IKT-használat rizikóját a szülők többsége a nemkívánt viselkedésben, azon belül a függővé válásban és az agresszív, erőszakos magatartásban látja. A válaszadók több, mit egyharmada szerint nem jó, hogy a gyermekek a „digitális kütyük” miatt elutasítják a valós, fizikai térben végzett tevékenységeket, kevesebbet mozognak és játszanak a társaikkal, miáltal beszükülnek a személyes jelenléttel járó kapcsolataik, például ritkulnak és időtartamban rövidülnek a közös családi programok. Közel ugyanennyien gondolják, hogy az IKT-tevékenység testi, kognitív, pszichés, és szocializációs zavarokat idéz elő. Vizsgálatukban az addikció után a második leggyakoribb félelem a technológiahasználat okozta egészségromlás. Legtöbben a szem- és látáskárosodástól tartanak, de említik még a gerincelváltozást, az idegrendszer és az agy túlterhelődését, az elhízást és a pszichés zavarokat is.

3. táblázat

Szülők válaszainak kategóriái az IKT-használat hatásairól óvodás korban

\begin{tabular}{|c|l|l|}
\hline Típus & \multicolumn{1}{|c|}{ Pozitív hatások } & \multicolumn{1}{|c|}{ Negatív hatások } \\
\hline Percepció & $\begin{array}{l}\text { Tudásépítés } \\
\text { (tanítás, fejlesztés, információ-szol- } \\
\text { gáltatás) } \\
\text { Technologizált világban való eligazo- } \\
\text { dás (eszközhasználat, jövőbe mutat) } \\
\text { Interperszonális kapcsolatépítés, } \\
\text {-tartás }\end{array}$ & $\begin{array}{l}\text { Nemkívánt viselkedés (függóség, } \\
\text { agresszió) } \\
\text { Nemkívánt tartalom (nem óvodá- } \\
\text { soknak való, agresszív, erőszakos, túl } \\
\text { magas izgalmi szintet generáló/ideg- } \\
\text { rendszert túlzottan terhelő) } \\
\text { Kiszorítás (játékot, mozgást, kapcso- } \\
\text { latokat) } \\
\text { Zavar (testi, kognitív, pszichés, } \\
\text { interperszonális) }\end{array}$ \\
\cline { 2 - 3 } & $\begin{array}{l}\text { Nincs, nem ismer ilyet } \\
\text { Attitűd }\end{array}$ & $\begin{array}{l}\text { Ellenőriz, kontrollál } \\
\text { Szükséges/nem szükséges, elutasít }\end{array}$ \\
\cline { 2 - 3 } & \multicolumn{2}{|l}{} \\
\cline { 2 - 3 } & \multicolumn{2}{|l}{$\begin{array}{l}\text { Korai, nem óvodásoknak való } \\
\text { Inkább mást tegyen }\end{array}$} \\
\hline
\end{tabular}

A szülők ebbéli aggodalmai nem alaptalanok. Az ezredfordulón több időt töltöttek elektronikus IKT-tevékenységgel, mint játékkal a szabadban (Rideoutet al., 2003). A kutatások már akkor összefüggést jeleztek a gyermekek technológiahasználata, a figyelemproblémák, illetve az alvászavarok között (Christakis et al., 2004; Paavonen et al., 2006). Kutatások tárgya az IKT-használat és a mozgásszervi elváltozások, valamint a túlsúly összefüggéseit, to- 
vábbá az olyan pszichés problémákkal való kapcsolatát, mint a szorongás, a félelem (például Eisenmann et al., 2008; Kenney \& Gortmaker, 2016; MoSuwan et al., 2014; Oswald et al., 2020). Kimutatták a médiaerőszaknak való kitettség és a gyermekek agresszív viselkedésének kapcsolatát (Anderson et al., 2003).

$\mathrm{Az}$ „Ön szerint milyen pozitív (jótékony) / negatív (káros) hatása lehet az IKT-eszközök használatának óvodás korban?" kérdésekre megfogalmazott vélemények összehasonlításából kiderül, hogy vannak olyan válaszelemek, amelyek mind pozitívumként és mind negatívumként jelen vannak. Ilyen például a médiafogyasztás tartalma. A szülők egy része úgy gondolja, jó használni a technológiát mesék, videók, képek nézésére, pozitív, hogy sokféle, a gyermekek számára vonzó játékot kínál stb. Mások szerint ellenben az elérhető tartalmak gyakran veszélyesek, buták, agresszívek és erőszakosak. Vannak, aki azt gondolják, hogy a számítógépes játékok segítik a gyermekek kognitív és pszichomotoros fejlődését, gyarapítják a tudásukat és vannak, akik szerint az ellenkezője történik. Egyes véleményekben az IKT-tevékenység fejleszti a gondolkodást, javítja a mozgáskoordinációt, koncentrációt, növeli a fantáziát, a kreativitást, más válaszok ezen területek zavarairól szólnak (például figyelemzavar). Sokan aggódnak, hogy az IKT, a digitális média hátérbe szorítja a valós, fizikai tevékenységeket (például mozgást), a gyermekek a videójátékok bűvöletében elutasítják a hagyományos fizikailag létező, megfogható eszközökkel és fizikailag jelen levő személyekkel, kortársakkal, megvalósuló játékokat.

Hasonlóan mindkét válaszcsoportban, a pozitív és a negatív hatások percepciói között egyaránt megtalálható az IKT mint a kapcsolattartás eszköze. Egyesek szerint az IKT megkönnyíti a családtagok kapcsolattartását, ugyanakkor többen vélik, hogy az a személyes (családi, baráti) kapcsolatok romlásához, befelé forduláshoz, elszigetelődéshez, elmagányosodáshoz vezet. Elemzésünk alapján úgy tünik, hogy a kutatásunkban véleményüket kifejtő szülők jellemzően nem számolnak sem a technológia kommunikációt, kapcsolatépítést támogató funkciójával, sem az internet veszélyeivel gyermekük eszközhasználatában. Ez valószínűleg a célcsoport életkori sajátosságaival van összefüggésben.

Mindkét kérdésre kaptunk olyan válaszokat, melyek szerint az IKT használatának nincs pozitív, illetve negatív hatása, illetve a válaszadó nem tud olyanokról. Ezeknek a szülőknek az aránya jóval kisebb a rizikófaktorok esetében. Míg 1,94\%-ban vélik, hogy az IKT-tevékenységnek nincs negatív következménye, illetve $0,71 \%$ nem ismer olyat, addig a 13,34\%-ban állítják, hogy nincs pozitív hatás és $2,39 \%$ nem tud róla.

A szülők egy csoportja valójában nem arról nyilatkozik, hogy mit gondol óvodáskorú gyermeke IKT-tevékenységének kívánt és nemkívánt következményeiről, hanem az infokommunikációs technológiával, annak használatával kapcsolatos attitűdjét fogalmazza meg. Mind a két kérdésre kapott válaszokban találkozunk az orosz szülőkre jellemző állásponttal (Chaudron et 
al., 2018), az IKT-használat elutasításával (nem szükséges, nem engedem), és olyan vélekedésekkel, hogy az nem a gyermekeknek való. Vannak, akik azt fejtik ki, hogy a gyermekeknek mit kellene inkább tenniük, ahelyett, hogy a képernyő előtt ülnek. Plowmann és munkatársaihoz (2010) hasonlóan mi is azt találtuk, hogy egyes szülők egyfajta nosztalgiája van: szerintük jobb, ha a gyermekeik inkább olyan tevékenységekkel foglaliák el magukat, amelyeket valaha, gyermekkorukban ők végeztek. - „Semmi pozitív, a gyermek fejlődéséhez mozgásra van szükség, illetve kreatív tevékenységekre” „Nem tudok negatív hatást, de szívesebben látom őt rajzolni vagy a friss levegőn játszani, mint ha gyakrabban használna IKT-eszközt."

Mint néhány bemutatott válasz mutatja, vannak szülők, akik a kontroll kontextusában gondolkodnak a digitális média hatásairól. Szerintük a gyermekek IKT-tevékenységének akkor van pozitív, illetve akkor nincs negatív következménye, ha ellenőrzik azt és korlátokat szabnak neki. - „A világ jobb megismerése, de nagyon szigorúan ellenőrizve és megszabva az időhatárt.” "Csak korlátozott ideig, felügyelet mellett használja, így nem tartom károsnak." - Mint azt korábban Clark (2011), valamint Donoso és Ribbens (2014) is megállapította ezek a szülők valószínűleg azt gondolják, hogy képesek kontrolálni, sikeresen mediálni gyermekeik IKT-használatát. Azt hiszik, hogy gyermekeik csak az általuk preferált IKT-tevékenységeket végzik (lásd Zartler et al., 2018). Úgy tűnik, mint arról a szakirodalom is beszámol, alábecsülik gyermekeik képességeit, digitális műveltségét (Donoso \& Ribbens, 2014), nincsenek tisztában a táblagépek tanulási potenciáljával (Brito \& Dias, 2016).

\section{Összegzés}

Ma a gyermekek a digitális médiával, a technológiával behálózott világban élnek és nőnek fel (Brito \& Dias, 2016.) A család attitüdjeitől függ, különösen kisgyermekkorban, hogy a digitális világ hogyan éri el, mennyiben „szippantja be" őket. A szülők általában, mint az idézett válaszok is jelzik, valamilyen formában felügyelik gyermekük IKT-fogyasztását, igyekeznek azt irányítani, adott keretek között tartani. Kutatásunk célja e közvetítő megnyilvánulásokat, annak konkrét történéseit meghatározó percepciók feltárása volt.

A kutatás általunk vizsgált fókuszának eredményeit összegezve elmondható, hogy a megkérdezettek más országokban élő kisgyermekes szülőkhöz hasonlóan gondolkodnak az IKT-tevékenység hatásairól. A válaszadók percepcióiban a digitális eszközök, az IKT jelenléte, használata a gyermekeikre nézve kívánt és nemkívánt következményekkel jár. A tartalomelemzés arra utal, amit például Seo és Lee (2017) is megfogalmazott, hogy a szülők inkább vannak tisztában a technológia veszélyeivel, mint annak előnyeivel. A lehetséges veszélyekről komplexebb, gyakran több rizikófaktort tartalmazó véleményeket fogalmaztak meg. De erre utal az is, hogy jóval többen vannak, akik azt nyilatkozták, hogy nem ismernek pozitív hatást. 
Vizsgálatunkban a szülők az IKT-használat jobbára már más kutatásokból ismert (Bakó \& Ráb, 2009; Chaudron et al., 2015; Donoso \& Ribbens, 2014; Jabbar et al., 2019; Kucirkova \& Littleton, 2016; Matsumoto et al., 2016; Papadakis et al., 2019) pozitívumait és negatívumait fogalmazták meg (tanulás, függőség, túlpörgés stb.). A szokásosan megnevezett következmények mellett (például mondókák, nyelvek tanulása, addikció, szemkárosodás stb.) azonban újabb információk is felszínre kerültek. A szülők körében végzett kutatások feldolgozott beszámolói nem említik a realitásfunkciók zavarát. Vizsgálatunkban az egyik, szülők által megfogalmazott aggodalom, hogy az óvodáskorú gyermekek nem tudják megkülönböztetni a valós és a virtuális világot, a létező és a kitalált dolgokat, élőlényeket. A kutatás másik jelentős hozama, hogy tovább finomította ismereteinket a szülők „kapuőr” viselkedését meghatározó attitüdjéről. Tudtuk, hogy vannak szülők, akik szükségtelennek tartják és teljes mértekben elutasítják az eszközhasználatot, sőt egyesek amennyire lehet igyekeznek azt kizárni gyermekük életéből. Matsumoto és munkatársai (2016) arról is beszámoltak, hogy vizsgálatukban a szülők álláspontjuktól függetlenül egyetértettek abban, hogy az IKT használatát lehetetlen és nem is ajánlott kikerülni. Arról azonban nem találtunk közléseket, hogy fennáll a környezet, a „technologizált világ” okozta „kényszer” miatti elfogadás is. Kutatásunkban nyilatkoztak úgy szülők, hogy az infokommunikációs technológia, a digitális média korunk meg-/kikerülhetetlen része, „ez a jelen”, ami nem feltétlenül jó, de el kell fogadni („Haladnia kell a korral, ismernie kell ezeket az eszközöket.” „A 21. századi gyerekként nem árt, ha tud róluk, ismeri. Rohamosan fejlődik e terület, az iskolában is használják már a tanórán, így nem marad le a társaitól.").

A megfogalmazott véleményekből kitűnik, a szülők egy része felismerte, hogy az IKT hatása önmagában nem, csak a használat paramétereinek (mit, mikor, mennyi ideig használják a gyermekek) függvényében értelmezhető. Érzi, hogy a szülő az, aki ebben meghatározó, aki kontrolálhatja gyermeke médiafogyasztását. Ô a „kapuőr”, aki megszűri az eszközhasználat tartalmát és megszabja annak kereteit, helyét, időpontját és időtartamát.

A szülőknek jellemzően nincsenek gyermekük nevelését célzó cselekvési stratégiái (Plowman et al., 2011) és döntéseik leggyakrabban intuitívak, inkább érzelmiek, mint racionálisak. Szükségük van gyermekük optimális IKThasználatát támogató útmutatásokra és mint Marsh és munkatársai (2015) kutatásukban leírják, örömmel fogadnának tanácsokat annak mediálásához. Az összegyüjtött válaszok segítségével pedig készíthetők döntéseiket segítő ajánlások.

\section{A kutatás elméleti és gyakorlati relevanciája}

A kutatás erőssége a feltáró nagymintás kvalitatív adatfelvétel, hasznosítható eredménye a szülők válaszainak kategóriarendszere. A nyitott kérdések alkalmazása lehetővé tette a célcsoport percepcióinak átfogó feltárását. 
Egy adatfelvétellel, egy mintában megjelentek az IKT-tevékenység hatásainak azon faktorai, amelyek eddig különböző kutatásokból eredményeiből voltak összerakhatók. A rizikófaktorok között megtalálhatók a pedagógiai és egészségtudományi szakértők által is azonosított kategóriák (lásd Kalaš, 2010) - ami egyben validálja is az eredményeket. - Másrészt a kitöltést nem befolyásolta a vélemények megfogalmazását orientáltó körülmény (az interjú kontextusa, például a mediációra irányuló kérdések, valamint előre megfogalmazott állítások, amelyekről csak dönteni kell). Így a több mint 1500 válasz valószínủleg a szülők kérdésekről való gondolkodását leinkább jellemző komponenseket tartalmazza, azokat, amelyeket ők mindenekelött az IKThasználat hasznának, illetve kárának tartanak.

Az ismert kutatások szülők véleményének feltárására használt mérőeszközei a nevelésben érintett szakértők, kutatók, pedagógusok, nevelési tanácsadók, valamint orvosok és pszichiáterek szaktudására alapozták tételeiket. Vizsgálatunk eredményei segítségével a kérdést empirikus tapasztalatok alapján átfogó, strukturált, új témákkal kiegészített zárt tételekből álló kérdőív(ek) szekeszthető(k). Szervezhetők workshopok, képzések, melyek segítik az érintettek - védőnők, szakértők, óvópedagógusok - munkáját, támogatják a szülők mediációját, válaszolnak kérdéseikre, feloldják a dilemmáikat.

Az elemzés felvetette a vizsgálat bővítését egy másik, a gyermekek saját eszközhasználatát jelentősen befolyásoló tényező vizsgálatának beemelésével, a szülők saját IKT-tevékenységük hatásairól való percepcióinak a feltárásával.

\section{A kutatás korlátai}

A kutatás egyik korlátja az adatfelvétel médiuma, a papír alapú kérdőív. A nyitott kérdésekre adott válaszok kódolásának problémáját részben megoldotta az általunk fejlesztett EKOD makrocsomag alkalmazása (B. Németh ez al., 2019). A papír alapú kérdőívfelvétel ugyanakkor előnyt is jelentett. Valószínű, hogy a magas kitöltésszám köszönhető a kérdező (az adatgyüjtő) és a kérdezett (adatszolgáltató) személyes találkozásának. Feltehetőleg inspirálta a szülőket a kérdőív kitöltésére az óvónők közreműködése és az intézménynyel való együttműködésre késztető attitűd. - A szülők általában próbálnak együttműködni az óvónőkkel, igyekeznek teljesíteni a kéréseiket. A kitöltés ugyan névtelen volt valószínűleg ösztönzőleg hatott, hogy az intézmények gyüjtötték össze a kérdőívet, hiszen nyilvánvaló volt, hogy ki nem töltötte ki, ki nem vitte azt vissza. 


\section{Irodalom}

B. Németh, M., Juhász, F., Hódi, Á. \& Tóth E. (2019). IKT eszközök használata óvodás korban - Egy kérdőív nyílt tételeinek kódolása EKOD makrócsomaggal. Gyereknevelés, 7(2-3), 170-186. https://doi.org/10.31074/201923170186

Bakó, M. \& Ráb, T. (2009). Számítógép-használat óvodáskorban. Iskolakultúra, 19(11), 89-101.

Bálint, V., Hódi, Á. \& Tóth, E. (2020). Óvodáskorú gyermekek otthoni IKT használati szokásai, attitűdjei, preferenciái. In Á. Engler, Rébay M. Magdolna, D.A.Tóth (Eds.), Országos Neveléstudományi Konferencia, Család a nevelés és oktatás fókuszában p. 324. 2020. november 5-7. Debrecen.

Barreto, S. \& Adams, S. K. (2011). Digital technology and youth: A developmental approach. The Brown University Child and Adolescent Behavior Letter.

Bavelier, D. \& Takeuchi, L. (2016). Digital game features and play contexts: Impact on learning and development. In C. S. Tamis-LeMonda \& Balter (Eds.), Child psychology: $A$ handbook of contemporary issues (3rd ed., pp. 451-471). Psychology Press.

Boon, H. J., Cottrell, A., King, D., Stevenson, R.B. \& Millar, J. (2012). Bronfenbrenner's bioecological theory for modelling community resilience to natural disasters. Natural Hazards, 60(2). 381-408. https://doi.org/10.1007/s11069-011-0021-4

Brito, R. (2016): Who taught you how play? Did you? Digital Practice and skills of children under 6. Media Education, 7(2), 281-302. https://doi.org/10.14605/ MED721607

Brito, R. \& Dias, P. (2016). The tablet is my BFF': Practices and perceptions of children un-der 8 years old and their families. In Í. Pereira, A.Ramo. \& J. Marsh (Eds.), The Digital Literacy and Multimodal Practices of Young Children: Engaging with Emergent (pp. 35-42). Centro de Investigação em Educação (CIEd) /Research Centre on Education Instituto de Edu-cação, Universidade do Minho.

Brito, R. \& Ramos, A. (2016). Online practices of children under 6: a grounded theory studyn. In I. Pereira, A. Ramo. \& J. Marsh (Eds.), The Digital Literacy and Multimodal Practices of Young Children: Engaging with Emergent (pp. 4350). Centro de Investigação em Educação (CIEd) / Research Centre on Education Instituto de Educação, Universidade do Minho: ISBN: 978-989-8525-48-2

Bronfenbrenner, U. (1977). Toward an experimental ecology of human development. American Psychologist, 32, 513-531. https://doi.org/10.1037/0003-066X.32.7.513

Bronfenbrenner U. (1979). The ecology of human development: Experiments by nature and design. Cambridge: MA: Harvard University Press.

Bronfenbrenner, U. (1994). Ecological models of human development. Readings on the Development of Children, 2(1), 37-43.

Bronfenbrenner, U. (1989). Ecological systems theory. In R. Vasta (Ed.), Annals of Child Development: Vol. 6 Six Theories of Child Development: Revised Formulations and Current Issues (pp. 187-249). JAI Press. 
Bronfenbrenner, U. \& Ceci, S. J. (1994). Nature-nurture reconceptualized in developmental perspective: A bioecological model. Psychological Review, 101(4), 568-586. https://doi.org/10.1037/0033-295X.101.4.568

Bronfenbrenner, U. \& Morris, P. A. (2006). The bioecological model of human development. In W. Damon (Series Ed.) \& R. M. Lerner (Vol. Ed.), Handbook of child psychology; Vol. 1: Theoretical models of human development (pp. 793828). Wiley. https://doi.org/10.1002/9780470147658.chpsy0114

Buckingham, D. (2015). Defining digital literacy. Nordic Journal of Digital Literacy 10 (anniversary issue), 21-34. https://www.idunn.no/file/pdf/66808541/defining digital_literacy_-_what_do_young_people_need_to_kn.pdf

Charmaz, K. (2003). Grounded theory: Objectivist and constructivist methods. In N.K, Denzin \& Y.S. Lincoln (Eds.), Strategies of Qualitative Inquiry (pp. 249291). Sage Publications.

Chaudron, S. (2015). Young Children (0-8) and digital technology: A qualitative exploratory study across seven countries. Publications Office of the European Union. https://doi.org/10.2788/00749

Chaudron, S., Beutel, M.E, Černikova, M., Navarette, V.D., Dreier, M., FletcherWatson, B., Heikkilä A.S., Kontríková, V., Korkeamäki, R.L., Livingstone, S., Marsh, J., Mascheroni, G., Micheli, M., Milesi, D., Müller, K.W. , Myllylä-Nygård, T., Niska, M., Olkina, O., Ottovordemgentschenfelde, S., Plowman, L., Ribbens, W., Richardson, J., Schaack C. , Shlyapnikov, V., Šmahel D., Soldatova, G. \& Wölfling, K. (2015). Young Children (0-8) and digital technology: A qualitative exploratory study across seven countries. EU report Luxembourg: Publications Office of the European Union. https://doi.org/10.2788/00749

Chaudron, S., Di Gioia, R. \& Gemo, M. (2018). Young children (0-8) and digital technology, a qualitative study across Europe; EUR 29070; https://doi. org/10.2760/294383

Chaudron S., Di Gioia R., Gemo M., Holloway D., Marsh J., Mascheroni G., Peter J. \& Yamada-Rice D. (2017). Kaleidoscope on the Internet of Toys - Safety, security, privacy and societal insights. Luxembourg. Publications Office of the European Union. doi: 10.2788/05383

Chiong, C. \& Shuler, C. (2010). Learning: Is there an app for that? Investigations of young children's usage and learning with mobile devices and apps. Joan Ganz Cooney Center. http://www-tc.pbskids.org/read/files/cooney_learning_apps.pdf

Cingel, D.P. \& Krcmar, M. (2013). Predicting Media Use in Very Young Children: The Role of Demographics and Parent Attitudes. Communication Studies, 64(4), 374-394. https://doi.org/10.1080/10510974.2013.770408

Clark, L.S. (2011). Parental mediation theory for the digital age. Communication Theory, 21(4), 323-343. https://doi.org/10.1111/j.1468-2885.2011.01391.x

Dardanou, M., Unstad, T., Brito, R., Dias, P., Fotakopoulou, O., Sakata, Y. \& O’Connor, J. (2020). Use of touchscreen technology by 0-3-yearold children: Parents' 
practices and perspectives in Norway, Portugal and Japan. Journal of Early Childhood Literacy, 20(3), 551-573. https://doi.org/10.1177/1468798420938445

Dias, P., Brito, R., Ribbens, W., Daniela, L., Rubene, Z., Dreier, M. \& Chaudron, S. (2016). The role of parents in the engagement of young children with digital technologies: Exploring tensions between rights of access and protection, from 'Gatekeepers' to 'Scaffolders.' Global Studies of Childhood, 6(4), 414-427. https:// doi.org/10.1177/2043610616676024

Donoso, V. \& Ribbens, W. (2014). Young children (0-8) and digital technology. A qualitative exploratory study - National report - Belgium, ICRI/CIR - KU Leuven.

Durak, A. \& Kaygin, H. (2020). Parental mediation of young children's internet use: Adaptation of parental mediation scale and review of parental mediation based on the demographic variables and digital data security awareness. Education and Information Technologies 25, 2275-2296. https://doi.org/10.1007/s10639-01910079-1

Eisenmann, J.C., Gentile, D.A., Welk, G.J, Callahan, R., Strickland S., Walsh, M., Walsh, D.A. (2008). SWITCH: rationale, design, and implementation of a community, school, and family-based intervention to modify behaviors related to childhood obesity. BMC Public Health, 8, 223. https://doi.org/10.1186/14712458-8-223

European Agency (2016). Inclusive early childhood education: An analysis of 32 European examples (P. Bartolo, E. Björck-Åkesson, C. Giné and M. Kyriazopoulou, eds.). European Agency.

Formby, S. (2014). Parents' perspectives: Children's use of technology in the Early Years. National Literacy Trust.

Gromek, M. (2018). Clarifying the blurry lines of FinTech Opening the Pandora's box of FinTech categorization. In R. Teigland, S. Shahryar, A. Larsson, A.M. Puertas, C. Bogusz (2018, Eds.), The rise and development of FinTech: Accounts of disruption from Sweden and beyond (pp. 168-189). London: Routledge, https:// doi.org/10.4324/9781351183628-10

Hatzigianni, M. \& Margetts, K. (2012). 'I am very good at computers': young children's computer use and their computer self-esteem. European. Early Childhood Education Research Journal, 20(1), 3-20. https://doi.org/10.1080/13 50293X.2012.650008

Hatzigianni, M. \& Margetts, K. (2014). Parents' beliefs and evaluations of young children's computer use. Australasian journal of early childhood, 39(4), 114-122. https://doi.org/10.1177/183693911403900415

Hódi, Á., Tóth, E., B. Németh, M. \& Fáyiné Dombi, A. (2019). Óvodások IKThasználata otthon - Szülői minta és szerepvállalás. Neveléstudomány, 6(2) 2241. https://doi.org/10.21549/NTNY.26.2019.2.2 
Holloway, D., Green, L. \& Livingstone, S. (2013). Zero to eight: Young children and their internet use. LSE, London: EU Kids Online. Retrieved from http://eprints. lse.ac.uk/52630/1/Zero_to_eight.pdf

Horst, H. A. (2010). Families. In M. Itō (Ed.), Hanging out, messing around, and geeking out: Kids living and learning with new media (pp. 149-194). MIT Press.

Jabbar, S., Al-Shboul, M., Tannous, A., Banat, S. \& Aldreabi, H. (2019). Young Children's Use of Technological Devices: Parents' Views. Modern Applied Science, 13(2), 66-80. https://doi.org/10.5539/mas.v13n2p66

Johnson, G.M. (2010). Internet Use and Child Development: Validation of the Ecological Techno-Subsystem. Educational Technology \& Society, 13(1), 176-185.

Johnson, G. \& Puplampu, K. (2008). Internet use during childhood and the ecological techno-subsystem. Canadian Journal of Learning and Technology / La revue canadienne de l'apprentissage et de la technologie, 34(1). https://doi. org/10.21432/T2CP4T

Johnson, K. (2014). Parental Perceptions of the Influence of Digital Media and Technology on Children's Reading Habits at Home. All Graduate Theses and Dissertations. 2186. https://digitalcommons.usu.edu/etd/2186.

Kabali, H. K., Irigoyen, M. M., Nunez-Davis, R., Budacki, J. G., Mohanty, S. H., Leister, K. P. \& Bonner, R. L. (2015). Exposure and use of mobile media devices by young children. Pediatrics, 136(6), 1044-1052. https://doi.org/10.1542/ peds.2015-2151

Kalaš, I. (2010). Recognizing the potential of ICT in early childhood education. UNESCO, Institute for Information Technologies in Education. UNESCO Institute for Information Technologies in Education

Kenney, E.L. \& Gortmaker, S.L. (2016). United States Adolescents' Television, Computer, Videogame, Smartphone, and Tablet Use: Associations with Sugary Drinks, Sleep, Physical Activity, and Obesity. The Journal of pediatrics, 182, 144149. https://doi.org/10.1016/j.jpeds.2016.11.015

Knowland, V \& Formby, S. (2016). The Use of Technology to Support Literacy in the Early Years. National Literacy Trust.

Kucirkova, N. (2011). Digitalised early years- Where next? New Voices, 24(12), 938-940

Lauricella, A.R., Wartella, E. \& Rideout, V.J. (2015). Young children's screen time: The complex role of parent and child factors. Journal of Applied Developmental Psychology, 36, 11-17. https://doi.org/10.1016/j.appdev.2014.12.001

Lips, M., Eppel, E., McRae, H., Starkey, L., Sylvester, A., Parore, P. \& Barlow, L. (2017). Understanding children's use and experience with digital technologies. Final research report.

Livingstone, S. \& Das, R. (2010). Media, communication and information technologies for the European family: A report for the Family Platform project, funded by the European Commission. LSE 
Livingstone, S., Haddon, L. \& Görzig, A. (2012, Eds.). Children, risk and safety on the internet: research and policy challenges in comparative perspective. Policy Press. https://doi.org/10.2307/j.ctt9qgt5z

Livingstone, S., Haddon, L., Görzig, A. \& Ólafsson, K. (2011). EU Kids Online II final report.

Livingstone, S., Marsh, J., Plowman, L., Ottovordemgentsschenfelde, S. \& FlecherWatson, B. (2014). Young children (0-8) and digital technology: qualitative exploratory study - national report. Joint researche Centre, Eurpean Commission.

Livingstone, S., Mascheroni, G., Dreier, M., Chaudron, S. \& Lagae, K. (2015) How parents of young children manage digital devices at home: The role of income, education and parental style. EU Kids Online, LSE.

Livingstone, S., Mascheroni, G., Staksrud, E. (2018). European research on children's internet use: assessing the past and anticipating the future. New Media and Siciety, 20(3), 1103-1122. https://doi.org/10.1177/1461444816685930

Lorenz, T. \& Kapella, O. (2020). Children's ICT use and its impact on family life (DigiGen - working paper series No. 1). https://doi.org/10.6084/ m9.figshare.12587975.v1

Marsh, J., Brooks, G., Hughes, J., Ritchie, L., Roberts, S. and Wright, K. (2005) Digital beginnings: Young children's use of popular culture, media and new technologies. Reportofthe'YoungChildren'sUseofPopularCulture,MediaandNewTechnologies' Study, funded by BBC Worldwide and the Esmée Fairbairn Foundation. Sheffield: University of Sheffield. http://www.digitalbeginnings.shef.ac.uk https://www.researchgate.net/publication/265183910_Digital_beginnings_ Young_children\%27s_use_of_popular_culture_media_and_new_technologies

Marsh, J., Mascheroni, G., Carrington, V., Árnadóttir, H., Brito, R., Dias, P. \& Trueltzsch-Wijnen, C. (2017). The Online and Offline Digital Literacy Practices of Young Children: A review of the literature. http://digilitey.eu/wp-content/ uploads/2017/01/WG4-LR-jan-2017.pdf

Marsh, J., Plowman, L., Yamada-Rice, D., Bishop, J.C., Lahmar, F., Scott, A., Davenport, A., Davis, S., French, K., Piras, M., Thornhill, S., Robinson, P. \& Winter, P. (2015). Exploring Play and Creativity in Pre-Schoolers' Use of Apps: Final Project Report. .

Matsumoto, M., Aliagas, Cr., Morgade, M., Correro, Cr.,Galera, N., Roncero, Cr. \& Poveda, D. (2016). Projects: Young Children and Digital Technology 0-8. A qualitative exploratory study. - A qualitative exploratory study National report - Spain. European Commission. Universidad Autónoma de Madrid, UAB. http:// hdl.handle.net/10486/669336. https://doi.org/10.13140/RG.2.1.4761.9442

Mo-Suwan, L., Nontarak, J., Aekplakorn, W. \& Satheannoppakao, W. (2014). Computer game use and television viewing increased risk for overweight among low activity girls: fourth Thai National Health Examination Survey 2008-2009. International Journal of Pediatrics, 2014:364702. https://doi. org/10.1155/2014/364702 
Nagy, V. \& Lehmann, M. (2016). A hagyományos és a számítógépes játékok hatása a gyerekekre. In G.Á., Vitályos \& M. Pintér, T. (Eds.), Mester és tanitvány II. Nemzeti Tehetség Program (pp. 125-143). Eötvös Loránd Tudományegyetem Tanító- és Óvóképző Kar.

O'Connor, J. \& Fotakopolou, O. (2016). A threat to childhood innocence or the future of learning? Parents' perspectives on the use of touch-screen technology by 0-3 year-olds in the UK. Contemporary Issues in Early Childhood, 17(2), 235247. https://doi.org/10.1177/1463949116647290

O'Neill, B. (2015). Ecological perspectives and children's use of the Internet: exploring micro to macro level analysis. Eesti Haridusteaduste Ajakiri. Estonian Journal of Education, 3(2), 32-53. https://doi.org/10.12697/eha.2015.3.2.02b

OfCom (2017). Children and parents: Media use and attitudes. Ofcom. https://www. ofcom.org.uk/research-and-data/media-literacy-research/childrens/childrenparents-2017

OfCom (2019). Children and parents: Media use and attitudes report 2018. Ofcom. https://www.ofcom.org.uk/research-and-data/media-literacy-research/ childrens/children-and-parents-media-use-and-attitudes-report-2018

Papadakis, S., Zaranis, N. \& Kalogiannakis, M. (2019). Parental involvement and attitudes towards young Greek children's mobile usage. International Journal of ChildComputer Interaction, 22, p. 100144. https://doi.org/10.1016/j.ijcci.2019.100144

Penn, H. 2005. Understanding early childhood education. Issues and controversies. Bell \& Bain Ltd.

Plowman, L. (2015). Researching young children's everyday uses of technology in the family home. Interacting with Computers, 27(1), 36-46. https://doi.org/10.1093/ iwc/iwu031

Plowman, L. (2016). Rethinking context: Digital technologies and children's everyday lives. Children's Geographies, 14(2), 190-202. https://doi.org/10.1080/1473328.2 015.1127326

Plowman L., Stevenson O., Stephen C. \& McPake J. (2012). Preschool children's learning with technology at home. Computers \& Education, 59(1), 30-37. https:// doi.org/10.1016/j.compedu.2011.11.014

Plowman, L. \& McPake, J. (2013). Seven myths about young children and technology. Childhood Education, 89(1), 27-33. https://doi.org/10.1080/00094056.2013.757 490

Plowman, L., McPake, J. \& Stephen, C. (2010). The technologisation of childhood? Young children and technology in the home. Children and Society, 24(1), 63-74. https://doi.org/10.1111/j.1099-0860.2008.00180.x

Rideout, V.J. (2017). The Common Sense Census: Media Use By Kids Age Zero To Eight. Common Sense Media.

Rideout, V.J. \& Hamel, E. (2006). The Media Family: Electronic Media in the Lives of Infants, Toddlers, Preschoolers, and Their Parents. Kaiser Family Foundation. 
Seo, H. \& Lee, C.S. (2017). Emotion Matters: What Happens Between Young Children and Parents in a Touchscreen World International Journal of Communication 11, 561-580. https://doi.org/1932-8036/20170005

Shin, W. \& Li, B. (2017). Parental mediation of children's digital technology use in Singapore. Journal of Children and Media, 11(1), 1-19. https://doi.org/10.1080/ 17482798.2016.1203807

Shin, W. (2015). Parental socialization of children's Internet use: A qualitative approach. New Media E Society, 17(5), 649-665. https://doi. org/10.1177/1461444813516833

Smahel, D., Machackova, H., Mascheroni, G., Dedkova, L., Staksrud, E., Ólafsson, K., Livingstone, S. \& Hasebrink, U. (2020). EU Kids Online 2020: Survey results from 19 countries. EU Kids Online. https://doi.org/10.21953/lse.47fdeqj01ofo

Strauss, A. \& Corbin, J. (1994). Grounded theory methodology: An overview. In N. K. Denzin \& Y. S. Lincoln (Eds.), Handbook of qualitative research (pp. 273-285). Sage Publication.

Thornton, M., Williams, J., McCrory, C., Murray, A. \& Quail, A. (2013). Growing up in Ireland, National Longitudinal Study of Children: Designe, Instrumentation and Procedures for the Infant Cohort at Wave One (9 Months). Department of Children and Youth Affairs.

Tomopoulos, S., Dreyer, B.P., Berkule, S., Fierman, A.H., Brockmeyer, C. \& Mendelsohn, Al. (2010). Infant Media Exposure and Toddler Development. Archives of Pediatrics \& Adolescent Medicine, 164(12):1105-1111. https://doi. org/10.1001/archpediatrics.2010.235.

Tudge, J. R. H. (2008). The everyday lives of young children: Culture, class, and child rearing in diverse societies. Cambridge University Press. https://doi.org/10.1017/ CBO9780511499890

Vélez-Agosto, N.M, Soto-Crespo, J.G., Vizcarrondo-Oppenheimer, M., VegaMolina, S. \& García Coll, C. (2017). Bronfenbrenner's Bioecological Theory Revision. Perspectives on Psychological Science, 12(5), 900-910. https://doi. org/10.1177/17456916177043

Wartella, E. A., Rideout, V., Lauricella, A. \& Connell, S. (2013). Parenting in the age of digital technology: A national survey. Report of the Center on Media and Human Development. Presented at the School of Communication, Northwestern University, Evanston, IL. http://cmhd.northwestern.edu/parenting-in-the-ageof-digital-technology/

Whitney, N.A. \& Chapman-Novakofski, K.M. (2014).Impact of Computer-Mediated, Obesity-Related Nutrition Education Interventions for Adolescents: A Systematic Review. Journal of Adolescent Health, 54(6) 631-645. https://doi.org/10.1016/j. jadohealth.2013.12.019

Zaman, B., Nouwen, M., Vanattenhoven, J., de Ferrerre, M. \& Van Looy, J. (2016). A Qualitative Inquiry into the Contextualized Parental Mediation Practices 
of Young Children's Digital Media Use at Home, Journal of Broadcasting E Electronic Media, 60(1), 1-22, https://doi.org/10.1080/08838151.2015.1127240

Zartler, U., Kogler, R. \& Zuccato, M. (2018). Digitale Medien im Vorschulalter. Perspektiven von Kindern und ihren Eltern. Retrieved from https://www. saferinternet.at/fileadmin/redakteure/Footer/Presse/Studienbericht_Digitale_ Medien_im_Volksschulalter.pdf 


\section{B. Németh, M, Hódi, Á., Juhász, F., Sárik, A. \& Tóth, E.}

\section{The views of parents of kindergarten-age children on the positive and negative effects of ICT use}

Increasing numbers of children under the age of 6 in Hungary are using ICT devices (Livingstone, Haddo \& Gorzig, 2012) and are exposed to the effects of technology in their homes. Family attitudes towards the use of ICT significantly influence the quantity and quality of the use of digital devices by preschoolers (Kalaš, 2010). Parents of preschool children often allow the use of ICT tools and digital content for development, pedagogy or leisure, and a significant proportion of them are highly aware users who pay careful attention to how their child uses ICT tools and learns about the program before allowing such use (Hódi , Tóth, B. Német \& Fáyné Dombi, 2019). However, an important piece of the puzzle that might shed light on the motives behind parental choices is missing: namely how parents view the positive and negative effects of ICT tools and how these views guide them in their children's digital socialization. The data reported in the present study aims to fill to this lacuna in the Hungarian context.

In our research in municipal, county seat -maintained kindergartens, we asked parents to share their views on the positive and negative effects of ICT use at the preschool stage. The question relating to the positive effects of the technology were answered by 1,507 (78.5\%), while that on negative effects by $1,545(82.14 \%)$ of the parents. The data were processed using the content analysis method.

In our study, the benefits of infocommunication technology are typically seen by parents in terms of knowledge acquisition, development and learning opportunities, and access to information. Respondents believe that early media experiences will prepare their children for later academic success and will make it easier for children to develop at school. Many respondents have positive views on digital media entertainment, as these keep children occupied when they are themselves busy.

The majority of parents see the risk of ICT use in addictive and aggressive, violent behaviour. More than a third of respondents think that ICT makes children reject real-world, physical activities, to engage in play less frequently with their peers, and to limit relationships requiring a personal presence. Parents also believe that media activity can cause physical, cognitive, mental, and socialization disorders.

The responses suggest that parents perceive the effects of ICT technologies as fundamentally positive in our case, too, but are less able to identify them. However, as in the case of other research, the above-mentioned risks fall into relatively well-defined categories (Chaudron, 2015; Kalaš, 2010)

Keywords: ICT use, parental views, positive effects, risks of ICT use

B. Németh Mária: https://orcid.org/0000-0003-4978-8743

Juhász Fruzsina: https://orcid.org/0000-0002-5608-6152

Hódi Ágnes: https://orcid.org/0000-0003-0325-1449

Sárik Anett: https://orcid.org/0000-0002-8506-7938

Tóth Edit: https://orcid.org/0000-0001-9281-5730 